\title{
Recent Developments in Fisheries Economics: An Introduction
}

\section{Ussif Rashid Sumaila, Gordon R. Munro, and Jon G. Sutinen}

The seven papers in this special issue, "Recent Developments in Fisheries Economics," cover a wide variety of recent issues in fisheries economics, and taken together they cover some of the latest developments in this field. ${ }^{1}$ The papers concern: (1) the location of marine protected areas (Arjan Ruijs and Johannus A. Janmaat); (2) individual vessel quotas and exclusive fishing rights (Frank Millerd; Frank Asche, Daniel V. Gordon, and Carsten L. Jensen); (3) fisheries subsidies (Colin Clark, Gordon R. Munro and Ussif Rashid Sumaila); (4) values from habitatdependent fisheries (Martin D. Smith); (5) data fouling (C. Michael Wernerheim and Richard L. Haedrich); and (6) rotational management of fishing grounds (Diego Valderrama and James L. Anderson).

Marine protected areas (MPAs) are, as the name implies, protected areas in the ocean and are designated ocean spaces within which human activities are regulated more stringently than elsewhere in the marine environment. The protection given by MPAs can vary widely, from minimal protection to full protection, that is, marine reserves or no-takes (Sumaila and Charles 2002). Such areas are carved out to maintain, at least to some extent, the natural environment of the designated area for ecological, economic, cultural, social, recreational, and other reasons. Often, MPAs are useful tools for fisheries management. In general, ecologists are quite positive about the potential of MPAs as a tool to help manage fisheries resources sustainably (Polacheck 1990; Pauly et al. 2002). However, many economists have

Land Economics - February 2007 • 83 (1): 1-5 ISSN 0023-7639; E-ISSN 1543-8325

(C) 2007 by the Board of Regents of the University of Wisconsin System been skeptical, even though increasingly more and more economists are acknowledging that MPAs could be a beneficial tool to support fisheries management efforts under uncertainty (Lauck et al. 1998; Sumaila 1998). In "Chasing the Spillovers: Locating Protected Areas in a TransBoundary Fishery," Arjan Ruijs and Johannus A. Janmaat, the authors demonstrate that MPAs can positively impact upon both marine biodiversity and fisheries returns, depending on whether nations sharing trans-boundary fish stocks act cooperatively or non-cooperatively. A differential game theoretic model is applied to analyze strategic behavior in MPA placement, and their effects on harvesting effort and biomass growth in two nations, if both nations implement an MPA. They show that the absence of cooperation can result in a prisoners' dilemma in MPA placement

The authors are, respectively, director, Fisheries Economics Research Unit, Fisheries Centre, University of British Columbia, Vancouver; Professor Emeritus, Department of Economics and Fisheries Centre, University of British Columbia, Vancouver; and professor, Environmental and Natural Resource Economics, University of Rhode Island.

We are grateful to the numerous sponsors of the 2005 NAAFE Forum, including: the U.S. National Marine Fisheries Service, NOAA; the University of British Columbia (the Faculty of Graduate Studies; the Sea Around Us Project; the Fisheries Economics Research Unit; Hampton Research Endowment Fund); Aquatic Ecosystem Science Section, Province of British Columbia; Canadian Sablefish Association; Octaform Concrete Forming Systems; and the Natural Resources Defense Council. Finally, we thank the reviewers, whose inputs have definitely contributed to the quality of the special issue.

${ }^{1}$ These seven articles in the special issue, "Recent Developments in Fisheries Economics," were selected from papers that were presented at the 2005 North American Association of Fisheries Economics Forum, which took place on May 25-27, 2005, at the University of British Columbia, Vancouver, Canada. The papers can be seen at (http://oregonstate.edu/Dept/IIFET/NAAFE/ 2005Forum.html). 
and effort. They argue that strategic interactions lead to a divergence between socially or ecologically optimal MPAs and those chosen by national governments.

Individual transferable quotas (ITQs) seek to give their owners exclusive and transferable rights to harvest a given portion of the total allowable catch of fish. Authorities establish total allowable catches (TACs), and then divide this among the individual fishers or firms in the form of individual harvest quotas, usually as a percentage of the TAC. These ITQs are transferable through selling and buying in an open market. In theory, ITQs are de facto property rights. If effective, ITQs will reduce the drive to "race for the fish," and create an incentive among fishers to regard the fishery resources as assets which promise to deliver a stream of economic benefits over the long run (Moloney and Pearse 1979; Squires et al. 1998). Hence, the tendency on the part of fishers to overexploit the resource should be lessened (Munro and Pitcher 1996). ITQs are primarily an instrument for promoting economic efficiency (Hannesson 1996). Many studies of ITQ systems in operation from around the world show that economic efficiency does indeed improve with the implementation of ITQ schemes (Munro and Pitcher 1996; Grafton 1996; Arnason 1997). However, the role of ITQs in the conservation of the resources and the ecosystems that support them through time, and the ensuring equity in the use of these resources is still controversial (Davis 1996; McCay, Apostle, and Creed 1998; Hersoug 2004; Macinko and Bromley 2004).

Frank Millerd, in his contribution: "Early Attempts at Establishing Exclusive Rights in the British Columbia Salmon Fishery," gives an interesting account of how the attempts of British Columbia, in the early 1900s, to introduce exclusive rights in its salmon fishery failed due to equity concerns. This account is a demonstration of how, even though a management measure may be economically efficient, it can still fail if equity concerns are not adequately met. Frank Asche, Daniel V.
Gordon, and Carsten L. Jensen discuss "Individual Vessel Quotas and Increased Fishing Pressure on Unregulated Species." They assert that, when individual vessel quotas are used in fisheries management, quotas are in most cases set species by species. Often these species are the most valuable and important of the target species. The authors model fishermen behavior and conduct an empirical analysis to show that for the most valuable species, there is a one-to-one relationship between changes in quota and changes in the harvest of unregulated species.

Fisheries subsidies are currently topical in international and national fisheries management institutions, and there are many valid reasons for this. First, fisheries subsidies are substantial globally, estimated to be between US\$ 15-20 billion annually (Milazzo 1998). In the North Atlantic region alone, Munro and Sumaila (2002) estimate an annual subsidy of about US\$ 2.5 billion. Second, this amount is normally paid by taxpayers and could therefore be used elsewhere more beneficially. Third, it is generally agreed by fisheries scholars that most fisheries subsidies help to increase fishing capacity to economically unsustainable levels, with the consequence that fish stocks end up being overexploited (Pauly et al. 2002; Clark, Munro, and Sumaila 2005). One subsidy that is still being viewed by many fisheries scholars and managers as having a positive, conservationist impact is buyback subsidies. Some economists argue that buyback subsidies, by leading to the removal of economically wasteful and resource threatening excess fleet capacity, make a positive contribution to resource management and conservation. Some, however, argue against the usefulness of buyback subsidies, arguing that these subsidies are basically ineffective as capital removed by them simply seep back into the fishery (Holland, Gudmundsson, and Gates 1999; Weninger and McConnell 2000). Clark, Munro, and Sumaila (2005) demonstrated that even if capital seepage does not occur after a buyback scheme, this class of subsidies could still be ineffective if fishers 
anticipate the future implementation of the buyback scheme-due to the time consistency problem (Kydland and Prescott 1977). In, "Buyback Subsidies, the Time Consistency Problem, and the ITQ Alternative," Colin W. Clark, Gordon R. Munro, and Ussif Rashid Sumaila, deal with the time consistency problem associated with buyback schemes, arising from the fact that the schemes may be anticipated by vessel owners. They discuss the consequences of combining buybacks with ITQ schemes, or the equivalent, instead of limited entry programs, and came to the conclusion that substituting ITQ schemes for limited-entry programs cannot be relied upon to eliminate fully the time consistency problem.

The impact of nutrient pollution on fisheries values is increasingly becoming of interest to policymakers, fishers, fisheries managers, and some environmental NGOs. The Dead Zone in the Gulf of Mexico and growing awareness of other eutrophic coastal waters have focused policy attention in the United States, in particular. Given the significant costs of reducing anthropogenic nitrogen and the policy challenges of dealing with multiple industries over largescale watersheds, it is necessary to study how much commercial fisheries benefits will increase from reductions in nutrient pollution and the corresponding improvements in estuarine habitat. This is studied in "Generating Value in Habitat-Dependent Fisheries: The Importance of Fishery Management Institutions," by Martin D. Smith. He explores this question using a bioeconomic model of the blue crab fishery in North Carolina's Neuse River Watershed. The analysis simulates dynamic rent and consumer surplus changes from a 30\% decrease in nitrogen loading under both open access (the status quo) and a partially rationalized fishery (constant total effort). The study discovered that producer benefits from the environmental quality change are higher for the rationalized fishery than for open access, but the benefits are of the same order of magnitude for some parameter values. Consumer benefits are larger than producer benefits and are comparable across institutions. However, the total benefits from improving environmental quality are small relative to the benefits from rationalizing the fishery and leaving environmental quality the same.

C. Michael Wernerheim and Richard L. Haedrich present "A Simple Empirical Model of Data Fouling by High-Grading in Capture Fisheries," that discusses the distortion of commercial landings data resulting from misreporting. Data fouling (legal or illegal) is considered one of the most serious problems facing fisheries managers, as it drives a wedge between what is actually caught and what is reported. The realization of the huge negative consequences of data fouling has led to a recent drive to solve the problem of illegal, unreported and unregulated (IUU) fishing by international organizations such as the OECD and the FAO. Earlier work in this area by Kuperan and Sutinen (1998), Sutinen and Kuperan (1999) and Charles, Mazany, and Cross (1999) have helped to shape the debate on how to employ economic instruments to combat this problem. Notable recent contributions in this regard are Sumaila, Alder, and Keith (2006) and Agnew (2005). The contribution of Wernerheim and Haedrich (2007) to this volume proposes an analytical model of data fouling that can be used with empirical data to estimate what they call the data fouling factor. The model is solved analytically for the profit-maximizing effort level and the associated number of high-grading operations. Using available data on the biology, harvesting technology, prices, and costs, they parameterize the model, solve it numerically, and derive some illustrative policy implications.

As a form of spatial management, rotational management of sedentary resources (which make up a significant share of fisheries catch) is a prominent issue in policy circles. Such policy discussions on rotational management have, however, been devoid of economic considerations. "Improving Utilization of the Atlantic Sea Scallop Resource: An Analysis of Rotational Management of Fishing Grounds," 
by Diego Valderrama and James L. Anderson is probably the first that conducts an empirical economic analysis of this issue. The authors developed an age-structured bioeconomic model to determine optimal patterns of exploitation for the U.S. Atlantic sea scallop fishery. Results indicate that economic rents are maximized by engaging in pulse fishing strategies, whereby fishing only occurs following a multi-year closure period. Closures allow biomass to accumulate undisturbed for several years in a row, leading to the harvest of premium-size scallops upon reopening of the fishing grounds. The study concludes that closures also result in substantial reductions in operating fishing costs.

\section{CONCLUSIONS}

We have presented a summary of the key issues analyzed in this special issue of the February 2007 Land Economics that is devoted to fisheries economics. In doing so, we also provide brief selected reviews of the literature on the topics studied by the seven papers; issues such as marine protected areas, individual transferable quotas, fisheries subsidies, habitat values, data fouling, and rotational management of sedentary fishery resources.

\section{References}

Agnew, D. J. 2000. "The Illegal and Unregulated Fishery for Toothfish in the Southern Ocean, and the CCAMLR Catch Documentation Scheme." Marine Policy 24 (50): 361-74.

Arnason, R. 1997. "Property Rights as an Organizational Framework in Fisheries. In Taking Ownership: Property Rights and Fishery Management on the Atlantic Coast, ed. B. L. Crowley, 99-144. Halifax, N.S.: Atlantic Institute for Market Studies.

Asche, F., D. Gordon, and C. Jensen. 2007. "Individual Vessel Quotas and Increased Fishing Pressure on Unregulated Species." Land Economics 83 (Feb.): 41-49.

Charles, A. T., R. L. Mazany, and M. L. Cross. 1999. "The Economics of Illegal Fishing: A Behavioural Model." Marine Resource Economics 14 (1): 95-110.
Clark, C. W., G. R. Munro, and U. R. Sumaila. 2005. "Subsidies, Buybacks and Sustainable Fisheries." Journal of Environmental Economics and Management 50 (1): 47-58.

2007. "Buyback Subsidies, the Time Consistency Problem, and the ITQ Alternative." Land Economics 83 (Feb.): 50-58.

Davis, A. 1996. "Barbed Wire and Bandwagons: A Comment on ITQ Fisheries Management." Reviews in Fish Biology and Fisheries 6 (1): 97-107.

Grafton, R. Q. 1996. "Individual Transferable Quotas: Theory and Practice." Reviews in Fish Biology and Fisheries 6 (1): 5-20.

Hannesson, R. 1996. "On ITQs: An Essay for the Special Issue of Reviews in Fish Biology and Fisheries." Reviews in Fish Biology and Fisheries 6 (1): 91-96.

Hersoug, B. 2002. Unfinished Business: New Zealand's Experience with Rights-Based Fisheries Management. Delft, The Netherlands: Eburon Academic Publishers.

Holland, D., E. Gudmundsson, and J. Gates. 1999. "Do Fishing Vessel Buyback Programs Work? A Survey of the Evidence." Marine Policy 23 (1): 47-69.

Kydland, F. E., and E. C. Prescott. 1977. "Rules Rather than Discretion: The Inconsistency of Optimal Plans." Journal of Political Economy 85 (3): 473-91.

Kuperan, K., and J. G. Sutinen. 1998. "Blue Water Crime: Deterrence, Legitimacy and Compliance in Fisheries." Law and Society Review 32 (2): 309-38.

Lauck, T., C. W. Clark, M. Mangel, and G. R. Munro. 1998. "Implementing the Precautionary Principle in Fisheries Management Through Marine Reserves." Ecological Applications 8 (1) Supplement: S72-S78.

Macinko, S., and D. W. Bromley. 2004. "Property and Fisheries for the 21st Century. Vermont Law Review 28 (3): 623-61.

McCay, B. J., R. Apostle, and C. F. Creed. 1998. "Individual Transferable Quotas, Comanagement and Community: Lessons from Nova Scotia." Fisheries 23 (1): 20-24.

Milazzo, M. J. 1998. "Subsidies in World Fisheries: A Re-examination." World Bank Technical Paper, No. 406, Fisheries Series. Washington, D.C.: World Bank.

Millerd, F. 2007. "Early Attempts at Establishing Exclusive Rights in the British Columbia Salmon Fishery." Land Economics 83 (Feb.): 23-40.

Moloney, D., and P. Pearse. 1979. "Quantitative Rights as an Instrument for Regulating Com- 
mercial Fisheries." Journal of the Fisheries Research Board of Canada 36:859-66.

Munro, G., and T. Pitcher. 1996. Editorial Comment. Reviews in Fish Biology and Fisheries 6 (1): 1-3.

Munro, G., and U. R. Sumaila. 2002. "Subsidies and Their Potential Impact on the Management of the Ecosystems of the North Atlantic." Fish and Fisheries 3 (4): 233-50.

Pauly, D., V. Christensen, S. Guenette, T. J. Pitcher, U. R. Sumaila, C. J. Walters, R. Watson, and D. Zeller. 2002. "Towards Sustainability in World Fisheries." Nature 418 (6898): 689-95.

Polacheck, T. 1990. "Year Around Closed Areas as a Management Tool." Natural Resource Modelling 4 (2): 327-53.

Ruijs, A., and J. Janmaat. 2007. "Chasing the Spillovers: Locating Protected Areas in a TransBoundary Fishery." Land Economics 83 (1): 6-22.

Smith, M. 2007. "Generating Value in HabitatDependent Fisheries: The Importance of Fishery Management Institutions." Land Economics 83 (1): 59-73.

Squires, D., H. Campbell, S. Cunningham, C. Dewees, R. Quentin Grafton, S. F. Herrick, J. Kirkley, S. Pascoe, and K. Salvanes, et al. (1998). "Individual Transferable Quotas in
Multispecies Fisheries." Marine Policy 22 (2): $135-59$.

Sumaila, U. R. 1998. "Protected Marine Reserves as Fisheries Management Tools: A Bioeconomic Analysis." Fisheries Research 37 (1-3): 287-96.

Sumaila, U. R., and A. Charles. 2002. "Economic Models of Marine Protected Areas: An Introduction." Natural Resource Modeling 15 (3): 261-72.

Sumaila, U. R., J. Alder, and H. Keith. 2006. "Global Scope and Economics of Illegal Fishing." Marine Policy 30 (6): 696-703.

Sutinen, J. G., and K. Kuperan. 1999. "A Socioeconomic Theory of Regulatory Compliance in Fisheries." International Journal of Social Economics 26 (1): 174-93.

Valderrama, D., and J. Anderson. 2007. "Improving Utilization of the Atlantic Sea Scallop Resource: An Analysis of Rotational Management of Fishing Grounds." Land Economics 83 (Feb.): 86-103.

Weninger, Q., and K. E. McConnell. 2000. "Buyback Programs in Commercial Fisheries: Efficiency versus Transfers." Canadian Journal of Economics 33 (2): 394-412.

Wernerheim, C. M., and R. L. Haedrich. 2007. "A Simple Empirical Model of Data Fouling in Marine Fisheries." Land Economics 83 (Feb.): $74-85$. 